\title{
POTENSI PAPUA SEBAGAI JALUR PERDAGANGAN INTERNASIONAL INDONESIA DENGAN KAWASAN PASIFIK
}

\author{
Rusdi J. Abbas ${ }^{1}$, Muhamad Firmansyah ${ }^{2 *}$, Frisca Lampita ${ }^{3}$. \\ ${ }^{1}$ Program Studi Hubungan Internasional, Universitas Pertamina \\ 2 Program Studi Hubungan Internasional, Universitas Pertamina \\ ${ }^{3}$ Program Studi Hubungan Internasional, Universitas Pertamina \\ *Korespondensi: firmansyahmuhamad540@gmail.com
}

\begin{abstract}
Indonesia an archipelagic country positioned between the Indian Ocean and the Pacific Ocean, created Indonesia's strategic position. Particularly in the Papua region as a potential international trade route. Considering the vital location and abundant resources, Papua has the capability as an international trade route that connects Indonesia's trade routes with the Pacific region. In a geopolitical perspective, communication line connectivity is the key for Indonesia to increase Indonesia's influence in trade relations in the Pacific region. Papua's position, which is directly adjacent to pacific countries considered to have strategic potential that can be the gateway to Indonesia-Pacific trade. Indonesia's presence in the Pacific region, through the connectivity of the Papua-Pacific trade route considered to be an important part of Indonesia's geopolitical maneuvers amid great power competition in the Pacific region. Through qualitative research methods and geopolitical analysis put forward by Jakub Grygiel, this research will strive to provide a recommendation of trade route connectivity strategy in Papua region by building land and maritime trade routes that have great potential for Indonesia's trade routes with the Pacific region.
\end{abstract}

Keywords: Indonesia, Papua, Pacific, Trade Routes, Geopolitics.

\begin{abstract}
ABSTRAK
Indonesia sebagai negara kepulauan yang terletak diantara Samudra Hindia dan Samudra Pasifik menjadikan wilayah Indonesia memiliki posisi yang strategis. Utamanya Papua sebagai jalur perdagangan internasional. Posisi geografis dan potensi sumber daya di dalamnya menjadi modal besar bagi Papua sebagai jalur perdagangan internasional yang akan menghubungkan jalur perdagangan Indonesia dengan kawasan Pasifik. Dalam perspektif geopolitik, konektivitas jalur komunikasi menjadi kunci utama bagi Indonesia untuk dapat meningkatkan pengaruh Indonesia dalam hubungan perdagangan di kawasan Pasifik. Posisi Papua yang berbatasan langsung dengan negara- negara Pasifik, dinilai memiliki potensi strategis yang dapat menjadi pintu masuk perdagangan Indonesia-Pasifik. Kehadiran Indonesia di kawasan Pasifik, melalui konektivitas jalur perdagangan Papua-Pasifik dinilai akan menjadi bagian penting dalam manuver geopolitik Indonesia di tengah persaingan kekuatan besar di kawasan Pasifik. Melalui metode penelitian kualitatif dan analisa geopolitik yang dikemukakan oleh Jakub Grygiel, penelitian ini akan berusaha untuk memberikan sebuah rekomendasi strategi konektivitas jalur perdagangan di
\end{abstract}


wilayah Papua dengan membangun rute perdagangan darat dan maritim yang memiliki potensi besar bagi jalur perdagangan Indonesia dengan kawasan Pasifik.

Kata Kunci : Indonesia, Papua, Pasifik, Jalur Perdagangan, Geopolitik.

\section{PENDAHULUAN}

Posisi geografis Indonesia sebagai negara kepulauan (archipelagic countries) yang berada diantara dua samudra besar, yaitu Samudra Hindia dan Samudra Pasifik menjadikan wilayah kepulauan Indonesia memiliki potensi besar sebagai jalur perdagangan internasional, termasuk dalam hal ini adalah wilayah Papua yang berpotensi sebagai jalur perdagangan internasional Indonesia dengan kawasan Pasifik. Optimalisasi jalur perdagangan yang masih sangat minim di wilayah Indonesia bagian timur, dinilai menjadi salah satu faktor yang menghambat hubungan perdagangan Indonesia dengan negara-negara Pasifik.

Pada tahun 2018 nilai perdagangan Indonesia dengan negara-negara Pasifik mencapai USD 10,67 miliar, bagi Indonesia kawasan Pasifik merupakan salah satu kawasan strategis bagi perdagangan Indonesia. Hal ini tidak terlepas dari adanya negara-negara kawasan Pasifik yang berpotensi menjadi mitra strategis bagi perdagangan Indonesia di kawasan Pasifik, diantaranya Australia, Papua New Guinea,
Fiji, Selandia Baru, dan Timor Leste (Kemendag, 2019). Potensi ini membuat Indonesia harus dapat mengoptimalisasikan hubungan perdagangan dengan kawasan Pasifik.

Kawasan Pasifik dinilai menjadi kawasan potensial bagi tujuan perdagangan Indonesia. Meskipun nilai perdagangan Indonesia dengan kawasan Pasifik dinilai masih belum sebesar perdagangan Indonesia dengan kawasan lain, seperti nilai perdagangan Indonesia dengan ASEAN yang mencapai US\$26,77 miliar pada tahun 2017 (Kemendag dalam Katadata.co.id, 2017).

Sedangkan total nilai perdagangan antara Indonesia dengan negara-negara di kawasan Pasifik di tahun 2018 mencapai US\$ 10,67 miliar yang meningkat dibandingkan dengan tahun sebelumnya yang hanya mencapai US\$ 10,37 miliar (Kemendag, 2019). Dalam implementasi manuver diplomasi ekonomi, Indonesia harus aktif dalam melakukan penetrasi perdagangan dengan pasar alternatif sebagai bagian dari strategi dalam menghadapi persaingan perdagangan dunia (Hutabarat,

131 Patensi Papua Sebagai Jalur Perdagangan Internasional Indanesia... 
2018).

Intensitas hubungan diplomatik yang dibangun oleh Indonesia dengan negaranegara kawasan Pasifik menjadi bagian penting bagi Indonesia untuk meningkatkan konektivitas perdagangan Indonesia Timur dengan kawasan Pasifik. Hal ini tidak terlepas dari adanya kepentingan Indonesia untuk dapat meningkatkan nilai perdagangan dengan negara-negara pasifik (Kementerian Perdagangan RI, 2019).

Optimalisasi perdagangan dengan kawasan Pasifik dinilai dapat dilakukan melalui optimalisasi konektivitas jalur perdagangan di kawasan Indonesia bagian timur, terutama wilayah Papua yang dinilai memiliki potensi besar bagi jalur perdagangan Indonesia dengan kawasan Pasifik. Hal ini tidak terlepas dari adanya hubungan sejarah yang dimiliki oleh Papua yang menjadi jalur perdagangan internasional pada abad ke-14 dan abad ke17, yang telah menjadi koridor maritim Indonesia. Papua telah memiliki sejarah panjang sebagai jalur perdagangan Nusantara. Pada sektor kekayaan sumber daya alam, Papua dinilai memiliki potensi besar yang harus dapat dioptimalisasikan bagi Indonesia untuk dapat meningkatkan komoditas perdagangan internasional, melalui wilayah Papua (Mahmud, 2014).

Dalam pandangan yang sama juga dijelaskan oleh Wuri Handoko (2010) dalam artikelnya yang berjudul "Gerak Niaga Maluku-Papua Zona Ekonomi dan Kekuasaan Islam". Artikel tersebut memberikan penjelasan mengenai hubungan sejarah perdagangan kepulauan Maluku dan Papua yang menjadi salah satu jalur strategis bagi perdagangan rempah-rempah dan hal ini memiliki implikasi yang luas terhadap konektivitas zona-zona perekonomian strategis antara wilayah Papua dan Maluku yang menjadi bagian penting dalam jalur perdagangan dan pelayaran internasional.

Secara posisi geografis, Papua yang berbatasan langsung dengan kawasan Pasifik dan Asia memiliki potensi besar bagi jalur perdagangan yang dapat menghubungkan kedua kawasan tersebut. Papua yang memiliki kedekatan geografis dengan negara-negara kawasan Pasifik, seperti Australia, Papua New Guinea, Vanuatu, Fiji hingga Selandia Baru dinilai menjadi potensi besar bagi Indonesia dalam upaya meningkatkan penetrasi pasarnya di kawasan Pasifik.

$$
\begin{array}{ccc}
\text { Dalam } & \text { pandangan } & \text { geopolitik, } \\
\text { meningkatnya } & \text { kehadiran negara-negara } \\
\text { besar, seperti } & \text { China, Australia, Selandia }
\end{array}
$$


Baru dan Amerika Serikat dalam percaturan geopolitik kawasan Pasifik, telah menjadikan kawasan ini sebagai salah satu arena strategis dalam persaingan geopolitik global (Dugis, n.d.). Isu-isu permasalahan Papua yang tidak dapat terlepas dari adanya pengaruh kekuatan asing, dinilai telah menjadi tantangan bagi Indonesia untuk dapat meningkatkan kehadiran mereka di wilayah Papua, salah satunya dengan membuka jalur perdagangan internasional melalui Papua.

Papua dinilai memiliki potensi sumber daya besar untuk menjadi jalur perdagangan internasional di kawasan Pasifik. Hal inilah yang menjadikan Papua dinilai akan menjadi arena penting bagi percaturan geopolitik Indonesia di kawasan Pasifik. Dalam pandangan geopolitik Ermaya Suradinata (2001), mendefinisikan geopolitik sebagai kemampuan suatu bangsa dalam melihat potensi dan kekuatan yang dimilikinya untuk dapat mencapai tujuan nasionalnya.

Pandangan yang sama juga dikemukakan oleh Jakub Gyrgiel. Dalam pandangannya, Grygiel menjelaskan bahwa dalam manuver geopolitik suatu negara harus dapat meningkatkan kapasitas kekuatannya dalam mengontrol kekuatan mereka terhadap potensi sumber daya dan jalur komunikasi yang dimiliki oleh wilayahwilayah strategis. Kekuatan sumber daya dan jalur komunikasi dinilai akan menjadi sebuah elemen penting oleh suatu negara untuk bersaing dan mempengaruhi kekuatan lain di dalamnya (Grygiel, 2006: 25-27).

Kemampuan negara dalam mengontrol sumber daya alam maupun sumber daya ekonomi dan jalur komunikasi dinilai akan meningkatan kapasitas kekuatan untuk mendominasi persaingan geopolitik global dan menjadi keuntungan bagi suatu negara, baik secara politik, ekonomi, maupun militer (Grygiel, 2006: 31).

Hal inilah yang membuat suatu negara dinilai harus dapat memiliki kemampuan untuk membangun kekuatan jalur komunikasi yang dapat dilakukan melalui pembangunan infrastruktur seperti, rel kereta api, pelabuhan, dan infrastruktur pendukung lainnya yang dapat meningkatkan konektivitas dengan kawasan tersebut (Grygiel, 2006: 29-31).

Melalui pemaparan geopolitik yang dikemukakan oleh Jakub Grygiel, penulis akan menggunakan pandangan geopolitik Grygiel untuk menganalisis posisi geografis wilayah Papua yang dapat dijadikan sebagai arena persaingan geopolitik Indonesia di kawasan Pasifik. 
Sehingga penelitian ini bertujuan untuk memberikan sebuah rekomendasi strategi bagi Indonesia untuk dapat memaksimalkan potensi Papua sebagai jalur perdagangan internasional Indonesia-Pasifik dengan memperhatikan berbagai aspek geopolitik di dalamnya.

\section{METODE}

Dalam penelitian ini, penulis menggunakan metode analisa deskriptif kualitatif melalui penggunaan teknik studi literatur dari berbagai sumber-sumber kepustakaan yang berasal dari buku, jurnal ilmiah, dan dokumen laporan resmi dari berbagai situs resmi pemerintahan (Creswell, 2014: 240).

Dalam penelitian ini penulis juga menggunakan situs-situs resmi pemerintahan Indonesia, diantara situs Kementerian Perdagangan Indonesia, Kementerian Luar Negeri Indonesia, dan Badan Pusat Statistik yang diperkuat dengan sejumlah berita dari berbagai situs berita yang kredibel.

Data-data yang telah diperoleh oleh penulis, akan masuk dalam teknik analisa deskriptif yang akan menjelaskan mengenai bagaimana dinamika sejarah perdagangan Papua hingga peta kekuatan geopolitik Papua. Diharapkan tulisan ini dapat
ISSN 2614-4336

VDL. 6 No. 2 HAL. 130-144

menghasilkan output analisis sejauh mana potensi Papua sebagai jalur perdagangan Indonesia-Pasifik dengan dinamika geopolitik yang ada di dalamnya.

\section{HASIL DAN PEMBAHASAN}

\section{Hubungan Perdagangan Indonesia dengan Negara-Negara Pasifik.}

Dalam hubungan perdagangan di kawasan Pasifik, Indonesia telah memiliki beberapa mitra penting di kawasan Pasifik, diantaranya:

\section{Hubungan Indonesia-Australia,} Australia merupakan mitra perdagangan terbesar bagi Indonesia di kawasan Pasifik. Pada tahun 2018 total perdagangan antara Indonesia dan Australia mencapai US\$ 8,6 juta yang menurun di tahun 2019 dengan total US\$ 7,8 juta. Pada nilai ekspor Indonesia di tahun 2018 mencapai angka US\$ 2,3 juta, sedangkan nilai impor Indonesia ke Australia mencapai nilai US\$ 5,5 juta (Statistik Kemendag, n.d).

Indonesia memiliki potensi ekspor ke Australia berupa kendaraan bermotor yang nilainya mencapai US\$201,6 juta, produk kertas rumah tangga dengan nilai mencapai US\$ 39,5, hingga kertas koran dan percetakan yang nilainya mencapai US\$ 40,6 juta. Sedangkan Australia memiliki potensi

134 Patensi Papua Sebagai Jalur Perdagangan Internasional Indanesia... 
ekspor biji gandum dengan nilai mencapai US\$ 1 miliar dan ekspor sapi Australia yang mencapai US\$ 236 juta (Arfandi \& Hertanti, 2019). Dalam hubungan perdagangan, Australia membutuhkan Indonesia sebagai pasar bagi komoditas pertanian dan peternakan (Setyawati \& Agussalim, 2015).

\section{Hubungan Indonesia-Papua New}

Guinea, Hubungan diplomatik antara Indonesia dengan Papua New Guinea telah terjalin sejak tahun 1975, Papua New Guinea merupakan salah satu mitra strategis bagi Indonesia di kawasan Pasifik. Secara letak geografis, Papua New Guinea yang berbatasan langsung dengan Papua (Indonesia) memiliki kedekatan hubungan politik dan ekonomi, termasuk dalam bidang perdagangan (Farneubun, 2016). Dalam neraca perdagangan Indonesia-Papua New Guinea di tahun 2019 tercatat surplus perdagangan Indonesia sebesar US\$ 93 ribu dari komoditas non-migas (Statistik Kemendag, n.d).

\section{Hubungan Indonesia-Selandia}

Baru, Hubungan diplomatik antara Indonesia dengan Selandia Baru dimulai sejak tahun 1958. Kedua negara memiliki hubungan strategis dalam menjaga stabilitas politik dan ekonomi kawasan. Selandia Baru merupakan mitra perdagangan terbesar bagi Indonesia di kawasan Pasifik setelah Australia.

Dalam hubungan perdagangan ekspor utama Indonesia ke Selandia Baru dalam bentuk komoditas kelapa sawit, karet, produk kehutanan, kertas, dan komoditas perkebunan lainnya. Sedangkan ekspor utama Selandia Baru ke Indonesia dalam bentuk komoditas susu bubuk, mentega, keju, daging, dan produk-produk olahan makanan (DPR RI, 2019).

\section{Hubungan Indonesia-Vanuatu,}

Hubungan perdagangan Indonesia dengan Vanuatu dapat dikatakan berjalan dengan sangat minim. Dimana nilai perdagangan kedua negara hanya mencapai US\$ 4 ribu pada tahun 2019 dengan nilai surplus perdagangan Indonesia dengan Vanuatu sekitar US\$ 3 ribu (Statistik Kemendag, n.d.).

Namun hubungan politik dan perdagangan kedua negara menjadi terhambat akibat sikap politik Vanuatu yang sering kali dianggap mengancam posisi kedaulatan Indonesia, terutama mengenai permasalahan HAM Papua (Fadhilah, 2019).

Hubungan perdagangan Indonesia di kawasan Pasifik bukan hanya dibangun dengan negara-negara tersebut, melainkan bervariasi. Seperti Fiji dengan nilai 
perdagangan mencapai US\$ 27 ribu dan Timor Leste dengan nilai perdagangan mencapai US\$ 217 ribu di tahun 2019 (Statistik Kemendag, n.d).

\section{Potensi Papua Sebagai Jalur Perdagangan Internasional}

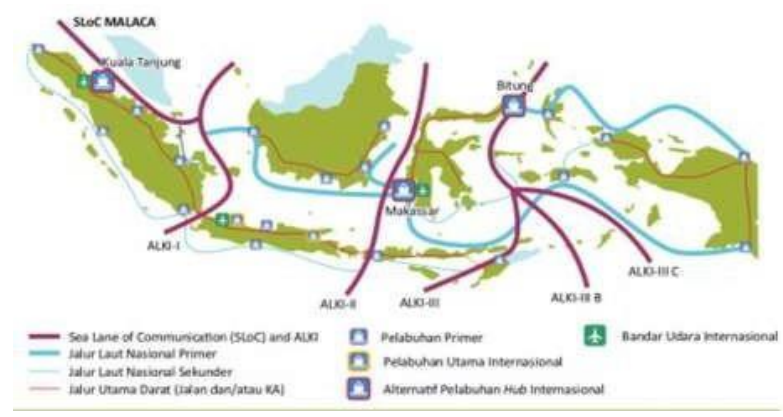

Gambar I. Alur Laut Kepulauan Indonesia Sumber: (https://1001indonesia.net/alur-lautkepulauan-indonesia/)

Berdasarkan letak geografis, Papua yang berada di wilayah Indonesia Timur memiliki posisi strategis di kawasan Pasifik. Secara posisi geografis Papua yang berbatasan langsung dengan Samudra Pasifik di utara dan Laut Arafura di selatan yang menjadi jalur lintas perairan menuju Australia, sedangkan wilayah sebelah timur Papua berbatasan langsung dengan Papua New Guinea dan sebelah barat berbatasan dengan Laut Banda (BPS, 2020).

Posisi geografis Papua pada wilayah daratan yang berbatasan langsung dengan Papua New Guinea telah menjadi sebuah jalur perdagangan lintas negara yang meliputi wilayah Papua, seperti Skouw, Arso, Waris, Senggi, Kiwirok Timur hingga wilayah Merauke yang berbatasan langsung dengan jalur perdagangan Papua New Guinea, seperti Wutungm Bewani, Imonda, hingga wilayah Mando (Timisela, 2015). Letak geografis Papua yang berbatasan langsung dengan Papua New Guinea dinilai akan menjadikan sebuah potensi besar untuk menjadi pintu masuk perdagangan rute darat dari kawasan Pasifik menuju Indonesia, begitu juga sebaliknya.

Letak geografis Papua bukan hanya memiliki potensi perdagangan pada rute darat, melainkan memiliki potensi strategis bagi jalur perdagangan Indonesia-Pasifik pada rute perairan internasional. Hal ini tidak terlepas dari adanya posisi geografis Papua yang berada di dalam garis strategis Alur Laut Kepulauan Indonesia (ALKI).

Indonesia merupakan negara kepulauan pertama yang telah menetapkan rute pelayaran internasional mereka melalui pembentukan tiga jalur ALKI berdasarkan ketentuan Konvensi Hukum Laut (UNCLOS) 1982. Tiga jalur utama tersebut: ALKI I menjadi jalur perairan dan pelayaran yang meliputi Laut Jawa, Natuna, Selat Malaka, Selat Sunda, dan Laut China Selatan yang dapat menjadi jalur perdagangan 
internasional yang terhubung dengan kawasan Laut China Selatan, Afrika, dan Samudra Hindia (Hutagalung, 2017).

ALKI II menjadi jalur pelayaran dan perairan yang meliputi wilayah Selat Lombok, Selat Makassar, Laut Sulawesi, dan Laut Lombok yang menjadi salah satu jalur perdagangan internasional di kawasan Asia Tenggara dan Australia, sedangkan pada ALKI III terbagi atas beberapa rute yang meliputi ALKI III A yang menghubungkan jalur perairan Samudra Pasifik, Selat Maluku, Selat Seram, Laut Banda yang terhubung dengan jalur pelayaran dan perdagangan internasional Australia dan Filipina (Hutagalung, 2017).

Rute berikutnya adalah ALKI III B yang menghubungkan jalur perairan dan perdagangan Selat Torres, Laut Arafuru, Laut Banda, dan Laut Maluku yang terhubung dengan jalur perdagangan internasional Australia, Selandia Baru, dan Samudra Pasifik. Sedangkan rute ALKI III C akan menjadi penghubung jalur pelayaran dan perdagangan Laut Maluku, Laut Banda, Selat Ombai, Laut Sawu yang akan terhubung dengan jalur perdagangan internasional Samudra Pasifik dan Samudra Hindia (Hutagalung, 2017).

Melalui penjabaran rute ALKI dengan skema rute diatas dapat dikatakan bahwa wilayah geografis Papua berada diantara rute ALKI III A-C yang menjadi bagian dari rute perdagangan internasional Samudra Pasifik, Samudra Hindia dan Australia melalui perairan Indonesia. Hal inilah menjadikan posisi geografis Papua yang berbatasan langsung dengan Laut Maluku, Laut Banda, dan Laut Arafuru dinilai sangat strategis untuk menjadi pintu masuk bagi perdagangan Indonesia bagian Timur, terutama menuju kawasan Selandia Baru dan Australia melalui rute perairan Laut Arafuru.

\section{Potensi Komoditas Perdagangan} Internasional Papua

Dalam hubungan perdagangan Indonesia-Pasifik, Papua menjadi salah satu wilayah Indonesia yang memiliki potensi nilai perdagangan Indonesia-Pasifik yang mencapai US\$ 10,67 miliar di tahun 2018, yang meningkat sebesar 3,05\% dibandingkan tahun sebelumnya (Kemendag, 2019).

Papua memiliki potensi kekayaan sumber daya alam yang dapat diekspor ke wilayah Pasifik, seperti Karet, Kakao, Kelapa Sawit, Pertambangan, Kopi hingga komoditas Perikanan. Komoditas ini dapat dijadikan komoditas strategis wilayah Papua (Jeratpapua.org, 2016). 
Tabel I. Komoditas Ekspor Papua 2017

\begin{tabular}{lcc}
\hline Komoditas & $\begin{array}{c}\text { Nilai Ekspor } \\
\text { US\$ }\end{array}$ & Presentase \\
\hline Tembakau & 452.802 & $0,02 \%$ \\
$\begin{array}{l}\text { Biji, Kerak, } \\
\text { dan Abu }\end{array}$ & 2.341 .210 .28 & $95,14 \%$ \\
$\begin{array}{l}\text { Logam } \\
\text { Komoditas }\end{array}$ & 3.891 .781 & $0,16 \%$ \\
$\begin{array}{l}\text { Karet } \\
\text { Produk kayu }\end{array}$ & 100.430 .276 & $4,08 \%$ \\
$\begin{array}{l}\text { Komoditas } \\
\text { lainnya }\end{array}$ & 11.842 .951 & $0,6 \%$ \\
\hline \multicolumn{1}{c}{ Sumber: Badan Pusat Statistik, 2017}
\end{tabular}

Sumber: Badan Pusat Statistik, 2017

Berdasarkan data Badan Pusat Statistik (BPS) menjelaskan dalam kurun waktu sepuluh tahun terakhir, Papua terus mengalami surplus perdagangan dengan nilai ekspor mencapai US\$2.007,52 juta dan nilai impor mencapai US\$746,72 juta di tahun 2015, secara perdagangan nasional Papua menyumbang sebesar $1,34 \%$ dari total nilai ekspor Indonesia tahun 2015 (BPS, 2016).

Peningkatan nilai komoditas perdagangan Papua juga semakin meningkat pada tahun 2017 dengan nilai mencapai US\$ 2.460,78 juta dan nilai impor mencapai US\$ 446,6 juta (BPS, 2018). Berdasarkan data BPS pada tahun 2017, Papua memiliki beberapa komoditas strategis yang di ekspor dalam perdagangan internasional.

Dalam konteks perdagangan internasional Indonesia-Pasifik, pangsa ekspor Papua masih didominasi di pasar
Papua New Guinea dengan nilai ekspor mencapai US\$ 47,91 juta dan Australia mencapai US\$ 0,21 juta pada tahun 2015 (BPS, 2016). Hingga tahun 2017 dalam sektor perdagangan internasional, Asia Pasifik masih menjadi pangsa utama dalam perdagangan internasional komoditas Papua.

Tabel II. Perdagangan Internasional Papua Antar Kawasan Tahun 2017

\begin{tabular}{lll}
\hline Kawasan & $\begin{array}{l}\text { Nilai Ekspor } \\
\text { (US\$) }\end{array}$ & $\begin{array}{l}\text { Nilai Impor } \\
\text { (US\$) }\end{array}$ \\
\hline Asia & 2.384 .866 .549 & 174.927 .171 \\
Pasifik & & \\
Eropa & 89.422 & 67.954 .129 \\
Amerika & 22.690 .273 & 31.631 .524 \\
Oceania & 412.268 & 172.052 .729 \\
\hline \multicolumn{3}{c}{ Sumber : Data BPS, 2017 }
\end{tabular}

Berdasarkan data-data tersebut, penulis menilai bahwa wilayah Papua memiliki komoditas-komoditas strategis yang dapat masuk ke dalam pasar internasional di sejumlah kawasan. Meskipun dalam hubungan perdagangan Papua dengan kawasan Pasifik masih dinilai sangat rendah. Melihat potensi komoditas strategis wilayah Papua dinilai menjadi sebuah potensi besar bagi Indonesia untuk meningkatkan hubungan perdagangan dengan kawasan Pasifik, terutama melalui wilayah Papua yang secara geografis memiliki posisi strategis sebagai jalur perdagangan internasional Indonesia-Pasifik. Besarnya 
potensi perdagangan internasional yang dimiliki oleh Papua bagi Indonesia, membuat pemerintah Indonesia dinilai harus dapat menyiapkan langkah-langkah strategis untuk dapat mengembangkan potensi wilayah Papua sebagai jalur perdagangan internasional Indonesia- Pasifik.

\section{Strategi Membangun Jalur Perdagangan}

\section{Internasional Papua Melalui Pendekatan}

\section{Geopolitik}

Percaturan politik internasional pada abad ke-21 tidak dapat terlepas pada persaingan dalam memperebutkan sumber daya ekonomi (economic resources). Ditengah persaingan kekuatan besar dalam konstelasi geopolitik global, membuat Indonesia dinilai harus dapat meningkatkan integrasi teritorialnya termasuk dalam mengamankan jalur-jalur perdagangan strategis. Jalur perdagangan internasional yang mencakup kekuatan sumber daya di dalamnya menjadi sebuah aset penting yang harus diperhatikan oleh Indonesia di tengah persaingan konstelasi politik internasional (Rustam, n.d.).

Namun dalam memandang posisi geografis suatu negara dalam konteks persaingan sumber daya ekonomi (economic resources), suatu negara harus memiliki pandangan geopolitik yang luas untuk meningkatkan bargaining position. Dalam pandangan Lidya C. Sinaga (n.d.), dinamika wilayah Papua dan kawasan di sekitarnya tidak dapat terlepas dari adanya persaingan manuver geopolitik kekuatan negara-negara besar. Hal inilah yang membuat Indonesia harus dapat melakukan pendekatan geopolitik dalam membangun potensi sumber daya di kawasan Papua.

Geopolitik dalam pandangan Grygiel menjelaskan bahwa untuk dapat meningkatkan power capability dan pengaruh suatu negara terhadap dinamika percaturan politik internasional, suatu negara harus dapat terlebih dahulu membangun jalur komunikasi meliputi pembangunan jalur kereta api, pelabuhan internasional, dan infrastruktur lainnya yang bertujuan untuk meningkatkan konektivitas terhadap suatu kawasan strategis dan akses sumber daya yang ada di dalamnya, termasuk sumber daya ekonomi (Grygiel, 2006: 25-26).

Konektivitas wilayah Papua dinilai menjadi sebuah kunci utama dalam membuka jalur perdagangan internasional yang dapat meningkatkan kehadiran Indonesia dalam persaingan geopolitik kawasan Pasifik. Kawasan Pasifik menjadi kawasan strategis yang memiliki arti penting

139 Patensi Papua Sebagai Jalur Perdagangan Internasional Indanesia... 
bagi Indonesia, hal ini tidak terlepas dari adanya posisi geografis kawasan Pasifik yang berbatasan langsung dengan Indonesia.

Secara letak geografis kawasan Pasifik, terutama kawasan Pasifik Selatan yang berbatasan langsung dengan Indonesia membuat Indonesia harus dapat membangun hubungan dengan penuh strategi. Hal ini tidak terlepas dari adanya keterlibatan negara-negara Pasifik Selatan yang berusaha menaruh pengaruh politik mereka terhadap wilayah Papua (Rianda et al., 2017).

Hal inilah yang membuat Indonesia, sejak tahun 2013 mulai mengorientasikan pendekatan yang lebih aktif terhadap kawasan Pasifik dengan membuka hubungan diplomatik dengan seluruh negara-negara Pasifik (Satriawan, 2016). Kehadiran Indonesia di kawasan Pasifik dinilai membutuhkan sebuah pintu masuk strategis yang dapat meningkatkan konektivitas hubungan Indonesia-Pasifik, terutama menyangkut hubungan perdagangan dan geopolitik Indonesia di kawasan Pasifik.

\section{Konektivitas Jalur Perdagangan}

Darat, Wilayah daratan geografis Papua yang berbatasan langsung dengan Papua New Guinea, memiliki posisi yang strategis bagi jalur perdagangan internasional Indonesia-
Pasifik melalui rute darat yang dapat menjadi pintu masuk bagi perdagangan kawasan Pasifik dengan Asia Tenggara. Hal inilah yang membuat wilayah Papua membutuhkan pembangunan infrastruktur pendukung, seperti jalur lintas negara, jalur kereta api, dan pipa-pipa energi yang dapat meningkatkan konektivitas jalur perdagangan dengan kawasan Pasifik, khususnya dengan Papua New Guinea.

Koridor ekonomi wilayah Papua yang akan terintegrasi dengan koridor perekonomian Maluku dinilai akan menjadi pintu masuk perdagangan Indonesia ke kawasan Pasifik, khususnya Papua New Guinea pada rute perdagangan darat. Dalam pandangan Farneubun (2016) Papua memiliki peranan strategis dalam mengintegrasikan kepentingan politik dan ekonomi Indonesia dengan Papua New Guinea.

Sehingga hal inilah yang membuat koridor ekonomi kawasan Papua dinilai sangat diperlukan dalam mempercepat konektivitas dan integrasi kawasan antara Indonesia dengan kawasan Pasifik. Dalam rute perdagangan Papua, konektivitas wilayah Sorong hingga ke wilayah Jayapura dan Merauke menjadi pintu masuk bagi peningkatan perdagangan Indonesia-Pasifik. 
Secara posisi geografis, kawasan Sorong (Papua) berada diantara jalur perdagangan internasional Samudra Pasifik dan Australia (Dewan Nasional Kawasan Ekonomi Khusus RI, n.d.).

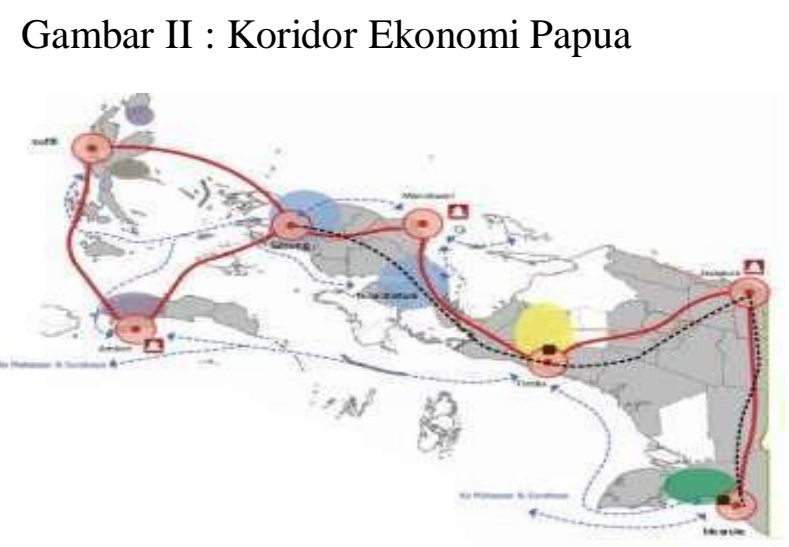

Sumber: BKP Provinsi Maluku (http://www.bkpmprov.net/2015/11/03/kori dor-ekonomi-papua-kepulauan-maluku)

\section{Konektivitas Rute Perdagangan}

Laut, Konektivitas perdagangan Indonesia dan Pasifik yang terhubung dengan wilayah perairan membuat pendekatan konektivitas perdagangan Indonesia-Pasifik, dinilai harus dapat dibangun melalui pembangunan rute pelayaran internasional, termasuk melalui perairan Papua. Secara historis wilayah perairan Papua-Maluku merupakan rute pelayaran internasional bagi perdagangan rempah-rempah di kawasan Asia Tenggara. Hal inilah yang membuat wilayah perairan Papua-Maluku menjadi wilayah economic zone di kawasan timur Indonesia (Handoko, 2010).

Hal ini semakin diperkuat dengan posisi geografis Papua, terutama pada beberapa titik strategis, seperti Sorong, Merauke, dan Jayapura sebagai titik strategis yang menjadi penghubung perdagangan Indonesia dengan kawasan Pasifik. Wilayah Sorong (Papua) yang berada di garis perdagangan Australia dan Samudra Pasifik juga memiliki potensi besar menjadikan kota Sorong sebagai pintu masuk perdagangan internasional Australia-Samudra Pasifik dan Indonesia-Pasifik (Dewan Nasional Kawasan Ekonomi Khusus RI, n.d.).

Manuver geopolitik Indonesia dalam gagasan Poros Maritim Dunia (PMD), seharusnya dapat mendorong peranan aktif Indonesia dalam meningkatkan konektivitas perdagangan maritim, terutama di wilayah Indonesia bagian timur khususnya Papua. Strategi konektivitas jalur perdagangan maritim Papua dapat dibangun dengan konsep "Spoke and Hub".

Strategi $H u b$ adalah dengan menjadikan kota Sorong, Jayapura, dan Merauke sebagai kota pelabuhan utama yang dapat menghubungkan perdagangan domestik dan internasional. Sedangkan strategi Spoke menjadikan kota Timika, 
Nabire, Kaimana, Wasior, Fak-Fak, Serui, Biak dan Manokwari sebagai pelabuhan pendukung dalam rute pelayaran dan perdagangan Papua (Natalia \& Agus, 2016).

\section{SIMPULAN}

Dinamika hubungan kerja sama perdagangan Indonesia dengan kawasan Pasifik yang masih terbilang rendah, membuat Indonesia harus dapat mengorientasikan pengembangan strategi perdagangan terhadap kawasan Pasifik ditengah persaingan geopolitik Kawasan Pasifik. Situasi inilah yang membuat Indonesia membutuhkan strategi khusus dalam meningkatkan manuver geopolitik mereka di kawasan Pasifik, salah satunya melalui jalur perdagangan. Indonesia harus dapat meningkatkan konektivitas jalur perdagangan Indonesia-Pasifik dengan menjadikan wilayah bagian timur Indonesia sebagai pintu masuk perdagangan IndonesiaPasifik, terutama di wilayah Papua.

Posisi geografis Papua yang berbatasan langsung dengan kawasan Pasifik dinilai akan dapat mendorong peningkatan pengaruh geopolitik Indonesia di kawasan Pasifik, melalui hubungan perdagangan. Konektivitas perdagangan melalui Papua menjadi sebuah pintu masuk strategis bagi
Indonesia untuk ikut serta dalam membangun peta kekuatan kawasan Pasifik di tengah persaingan kekuatan besar di dalamnya.

Potensi besar yang dimiliki oleh Papua sebagai jalur perdagangan internasional Indonesia-Pasifik harus dapat dioptimalisasikan oleh Indonesia dengan meningkatkan pembangunan jalur konektivitas perdagangan yang meliputi rute perdagangan darat dan laut melalui jalur perdagangan Papua. Dalam pandangan penulis, konektivitas perdagangan Indonesia di kawasan Pasifik melalui Papua, dinilai harus dibarengi dengan peningkatan kapasitas keamanan dan pertahanan Indonesia di wilayah Papua yang selama ini sering kali menjadi arena persaingan geopolitik yang dilakukan oleh negaranegara asing.

\section{DAFTAR PUSTAKA}

Arfandi and Hertanti. (2019). Analisis Kritis Kerjasama Indonesia-Australia CEPA: "Berpotensi Besar Meningkatkan Impor, Ketimbang Ekspor. Indonesia for Global Justice.

BKPM Provinsi Maluku Utara. (2015). Koridor Ekonomi Papua-Kepulauan Maluku. BKPM Maluku Utara. Diakses pada tanggal 28 September 2020 melalui: 
http://www.bkpmprovmalut.net/2015/1 1/03/koridor-ekonomi-papua-

kepulauan -maluku/.

BPS. (2020). Provinsi Papua Dalam Angka 2020. Badan Pusat Statistik Provinsi Papua 2020. ISSN: 0215-2312.

BPS. (2018). Statistik Ekspor-Impor Papua 2017. Badan Pusat Statistik Provinsi Papua 2018. ISSN: 2477-4502.

BPS. (2016). Statistik Ekspor-Impor Papua 2015. Badan Pusat Statistik Provinsi Papua 2016. ISSN: 2477-4502.

Creswell. (2014). Research Design: Qualitative, Quantitative, and Mixed Methods Approaches. (4 ${ }^{\text {th }}$ eds). London: SAGE Publication.

Dewan Nasional Kawasan Ekonomi Khusus Republik Indonesia. (n.d.). Master Plan KEK Sorong. Dewan Nasional KEK$R I$. Diakses pada tanggal 28 September 2020 melalui: https://kek.go.id/kawasan/Sorong.

DPR. (2019). Laporan Delegasi Grup Kerjasama Bilateral (GKSBB): DPR RI-Parlemen. Selandia Baru. DPR Republik Indonesia.

Dugis, V. (2015). Memahami Peningkatan Kehadiran China di Pasifik Selatan: Perspektif Realisme Stratejik. Jurnal Global \& Strategis 9 (1). DOI: 10.20473/jgs.9.1.2015.1-18.

Fadhilah, M. (2019). Inkonsistensi Kebijakan Luar Negeri Melanesia Spearhead Group (MSG) dalam Isu Papua Barat: Studi Kasus Fiji dan Papua Nugini. Indonesia Perspective, Vol. 4. No. 1 (59-81).
ISSN 2614-4336

VDL. 6 No. 2 HAL. 130-144

Farneubun. (2016). Indonesia-PNG Cooperation: Papua Strategic Roles. KnE Social Sciences, Vol. 2016. DOI: 10.18502/kss.v1il.447.

Grygiel. J. (2006). Great Power and Geopolitic Change. USA: John Hopkins University Press. pp: 20-35. ISBN: 0-8018-8480-2.

Handoko, W. (2010). Gerak Niaga Maluku-Papua Zona Ekonomi dan Kekuasaan Islam. Jurnal Papua, Vol. 2, No. 1 .

Hutabarat. (2018). Diplomasi Ekonomi Indonesia dan Pasar Prospektif di Kawasan Pasific Alliance: Studi Kasus Meksiko dan Chile. Jurnal Asia Pasific Studies, Vol. 2, No.2.

Hutagalung, S.M. (2017). Penetapan Alur Laut Kepulauan Indonesia (ALKI): Manfaatnya dan Ancaman Bagi Keamanan Pelayaran di Wilayah Perairan Indonesia. Jurnal Asia Pasific Studies, Vol. 1, No.1.

Jeratpapua.org. (2016, April 12). Pemprov Dorong Lima Unggulan Komoditas Papua. jeratpapua.org. Diakses pada tanggal 28 September 2020. melalui: https://www.google.com/amp/s/www.j eratpapua.org/2016/04/12/pemprovdorong-lima- unggulan-komoditaspapua/amp/.

Kemendag. (2019, Juli 12). Kemendag Perkuat Ekspor ke Kawasan Pasifik. Kementerian Perdagangan Republik Indonesia. Diakses pada tanggal 28 September $2020 \quad$ melalui: https://www.kemendag.go.id/id/newsro om/media-corner/kemendag-perkuatekspor-ke- kawasan-pasifik-1. 
Kemendag. (2017, Juli 11) dalam Katadata.co.id (2017). Berapa Perdagangan Indonesia dengan Negara ASEAN?. Katadata.co.id. Diakses pada tanggal 28 September 2020. Melalui:https://databoks.katadata.co.id/ datapublish/2017/08/11/berapaperdagangan-indonesia-dengan-negaraasean.

Mahmud. (2014). Komoditas dan Dinamika Perdagangan di Papua Masa Sejarah. Jurnal Berkala Arkeologi, Vol. 34, No.2 (183-198).

Natalia \& Agus. (2016). Desain Rute Pelayaran Sistem Hub and Spoke (Studi Kasus: Wilayah Papua, Indonesia). Jurnal Metris, Vol. 17 (113-122).

Rianda et al. (2017). Kebijakan Luar Negeri Indonesia Terhadap Dukungan Republik Vanuatu Atas Kemerdekaan Papua Barat Tahun 2015-2016. Jurnal Dinamika Global, Vol. 2, No. 1.

Rustam, Ismah. (n.d.). Tantangan ALKI dalam Mewujudkan Cita-Cita Indonesia sebagai Poros Maritim Dunia. Indonesia Perspective, Vol. 1, No. 1 (1-21).

Satriawan. (2016). Kebijakan Indonesia Membuka Hubungan Diplomatik dengan Negara- Negara Kawasan Pasifik (Tuvalu, Nauru, Karibati). Jurnal JOM FISIP, Vol. 3, No.2.

Setyawati and Agussalim. (2015). Security Complex Indonesia-Australia dan Pengaruhnya terhadap Dinamika Hubungan Kedua Negara. Jurnal Ilmu Sosial dan Ilmu Politik, Vol. 19. No.2 (111-124).
Sinaga, Lidya C. (n.d.). Menilik Alur Laut Kepulauan Indonesia II. Pusat Penelitian Politik. Diakses pada tanggal 28 September 2020 melalui: http://www.politik.lipi.go.id/in/kolom/ politik-internasional/413-menilik-alurlaut-kepulauan-indonesia-ii.html.

Statistik Kemendag. (n.d). Neraca Perdagangan Dengan Mitra Dagang. Kementerian Perdagangan Republik Indonesia. Diakses pada tanggal 28 September $2020 \quad$ melalui: https://statistik.kemendag.go.id/balanc e-of-trade-with-trade-partner-country.

Suradinata, Ermaya. (2001). Geopolitik dan Geostrategi Dalam Mewujudkan Integritas Negara Kesatuan Republik Indonesia. Jurnal Ketahanan Nasional, Vol. 6, No.2.

Timisela, Sinyo. (2015). Dampak Perdagangan Lintas Batas Terhadap Perekonomian Masyarakat Lokal (Studi Kasus: Wilayah Perbatasan RIPNG di Distrik Muara Tami). JESP, Vol. 7, No. 2. ISSN: 2086-15.

\section{PROFIL SINGKAT}

Rusdi J. Abbas pada periode 2010 sampai dengan 2016, melanjutkan pendidikan doktor di Universitas Marmara Istanbul Turki, pada Jurusan Administrasi Publik. Saat ini aktif sebagai tenaga pengajar (Dosen) di Program Studi Hubungan Internasional, Universitas Pertamina. 